\title{
DAYA MENGIKAT AIR DAN SUSUT MASAK DAGING SAPI BLANSIR YANG DIKERINGKAN DALAM OVEN DAN DIKEMAS VAKUM
}

\author{
John Ernst Gustaaf Rompis
}

Fakultas Peternakan Universitas Sam Ratulangi Manado, 95115

\begin{abstract}
ABSTRAK
Daging segar ditinjau dari komposisinya, termasuk bahan pangan yang mudah mengalami perubahan fisik, kimia yang menyebabkan kerusakan dan penurunan mutu. Kerusakan ini terjadi karena dalam daging segar mengandung zat-zat makanan bernilai gizi tinggi yang merupakan media utama bagi pertumbuhan mikroba. Kerusakan tersebut dapat ditangani melalui pengeringan dan pengemasan vakum terhadap daging sapi blansir dan disimpan pada suhu kamar.Tujuan penelitian adalah mengetahui pengaruh lama pengeringan dan lama penyimpanan pada suhu kamar terhadap daya mengikat air (DMA) dan susut masak (SM) pada daging sapi blansir yang dikemas vakum.Penelitian ini menggunakan rancangan acak lengkap berpola petak terbagi dalam waktu $3 \times 4$ berulangan 3 . Lama pengeringan (jam) pada suhu $60^{\circ} \mathrm{C}$ sebagai faktor $\mathrm{A}$ (petak utama) $\mathrm{A}_{1}=12 ; \mathrm{A}_{2}=$ 16; dan $\mathrm{A}_{3}=20$. Faktor $\mathrm{B}$ (anak petak) adalah lama penyimpanan (hari) pada suhu kamar $27^{0} \mathrm{C}$ yaitu $\mathrm{B}_{0}=0 ; \mathrm{B}_{1}=12 ; \mathrm{B}_{2}=24 ;$ dan $\mathrm{B}_{3}=$ 36. Hasil penelitian menunjukkan bahwa perlakuan berpengaruh sangat nyata $(\mathrm{P}<0,01)$ pada ketiga peubah yang diukur. Interaksi antara kedua faktor tersebut berbeda tidak nyata $(\mathrm{P}>0,05)$ pada DMA dan SM. Hasil penelitian menunjukkan bahwa daging sapi blansir yang dikeringkan selama 16 jam pada suhu $60^{\circ} \mathrm{C}$ dan dikemas vakum serta disimpan pada suhu kamar $27^{\circ} \mathrm{C}$ selama 36 hari menghasilkan DMA dan SM dalam standar normal.
\end{abstract}

Kata Kunci: daya mengikat air, susut masak, daging sapi blansir, pengemasan vakum

\begin{abstract}
WATER HOLDING CAPACITY AND COOKING LOSS OF DRIED AND VACUUM PACKAGE BEEF MEAT. Fresh meat is categorized into perishable physical and chemical material product due to high nutrient composition as the main media of growing microorganism. This meat damage could be handled by drying and vacuum package method. The objective of this study was to evaluate effect of drying time period and storage time period on water holding capacity and cooking loss of vacuum package beef meat. Treatment was conducted using completely randomized design divided into two factors with three replications in each combination of the factors. Factor A, as main plot of drying time period was divided into 12 hours $\left(A_{1}\right), 16$ hours $\left(A_{2}\right)$ and 20 hours $\left(A_{3}\right)$. Factor $\mathrm{B}$ as sub plot of storage time period in room temperature of $27^{\circ} \mathrm{C}$ was divided into $0^{0}$ $\mathrm{C}\left(\mathrm{B}_{0}\right), 12^{0} \mathrm{C}\left(\mathrm{B}_{1}\right), 24^{0} \mathrm{C}\left(\mathrm{B}_{2}\right)$, and $36^{\circ} \mathrm{C}\left(\mathrm{B}_{3}\right)$. Results showed that treatments affected significantly quality of beef meat. There was no interaction effect on water holding capacity and cooking loss of vacuum package beef meat. Beef meat being dried during 16 hours with temperature of $60{ }^{0} \mathrm{C}$ using vacuum package and stored at room temperature of $27^{\circ}$ $\mathrm{C}$ during 36 days produced normal standard of water holding capacity and cooking loss of meat.
\end{abstract}

Key words: water-holding capacity, cooking loss, vacuum package. 


\section{PENDAHULUAN}

Daging merupakan jaringan otot ternak yang telah terhenti fungsi fisiologisnya setelah pemotongan dan terdapat dalam porsi yang paling besar di samping karkas lainnya.Selain itu daging memiliki nilai nutritif yang tinggi, karena bagian terbesar dalam bahan keringnya adalah protein dengan kandungan asam amino yang lengkap dan seimbang. Komposisi kimia daging sapi yaitu $75 \%$ air, $18 \%$ protein, 2,5\% lemak, 1,2\% karbohidrat dan 2,3\% zat terlarut bukan protein serta selebihnya adalah vitamin dan unsur organik. Untuk ternak ruminansia berukuran besar seperti sapi, otot yang biasa digunakan untuk pengujian adalah daging bagian paha belakang.

Daya mengikat air (DMA) oleh protein daging atau water holding capacity (WHC) atau water binding capacity (WBC) adalah kemampuan daging untuk mengikat airnya atau air yang ditambahkan selama ada pengaruh kekuatan dari luar, misalnya pemotongan daging, pemansan, penggilingan dan tekanan absorbs air atau kapasitas (kemampuan daging menyerap air secara spontan dari lingkungan yang mengandung cairan (Soeparno,2005). Air yang terikat dalam daging dibagi tiga komponen yaitu air diikat secara kimiawi oleh protein daging sebesar $4-5 \%$ yang merupakan lapisan monomolekuler pertama, lapisan kedua adalah air yang terikat agak lemah dari molekul air terhadap kelompok hidrofilik yakni sebesar 4\% dan pada lapisan ketiga merupakan air bebas di antara molekulmolekul protein yang memiliki jumlah terbanyak(Wismer-Pedersen, 1987). Lanjut dikatakan bahwa jumlah air yang terikat (lapisan pertama dan kedua) adalah bebas dari perubahan molekul yang disebabkan oleh denaturasi protein daging, sedangkan jumlah air terikat lebih lemah, yaitu diantara molekul protein dan akan menurun bila protein daging mengalami denaturasi. Menurut Aberle et al. (2012) protein adalah salah satu bagian yang terpenting dalam komponen serabut otot.Protein otot dikategorikan sebagai sarkoplasmik, myofibril dan stromal protein berdasarkan tingkat kelarutannya.Porsi terbesar air dalam daging ditahan di myofibril, di antara myofibril dan antara myofibril dengan membrane sel (sarcolemma), antara sel otot dan antara grup sel otot (HuffLonergan dan Lonergan, 2005). Lanjut dikatakan bahwa lean muscle mengandung $74 \%$ air, 25\% komponen lainnya (19\% protein, 5\% lemak, $1 \%$ mineral dan vitamin). Susut masak (SM) merupakan salah satu indikator nilai nutrisi daging yang berhubungan dengan kadar jus 
daging yaitu banyaknya air yang terikat di dalam dan di antara serabut otot(Soeparno, 2005). Lanjut dikatakan bahwa SM dipengaruhi oleh temperatur dan lama pemasakan. Semakin tinggi temperatur pemasakan maka makin besar kadar cairan daging yang hilang sampai mencapai tingkat yang konstan. Besarnya SM dipengaruhi oleh banyaknya kerusakan membran seluler, banyaknya air yang keluar dari daging, umur simpan daging, degradasi protein dan kemampuan daging untuk mengikat air (Shanks et al., 2002).Blansir merupakan pemanasan pendahuluan bahan pangan pada suhu mendidih dalam waktu singkat.Soeparno (2005) mengatakan bahwa $80^{\circ} \mathrm{C}$ adalah temperatur yang ideal dan popular untuk perlakuan thermal (panas) karena sampel daging menjadi cukup tepat kekerasannya untuk dipotong-potong menjadi sub sampel pengujian kualitas.

Pengeringan adalah suatu proses pengeluaran air yang terdapat dalam bahan pangan dengan menguapkan atau menyublimkan air tersebut sebagian atau seluruhnya (Karel dan Lund, 2003). Biasanya kandungan air bahan dikurangi sampai batas tertentu dimana mikroba tidak dapat tumbuh lagi pada bahan tersebut (Muchtadi dan Sugiono, 2013).Selanjutnya dikatakan bahwa pengeringan berdasarkan prosesnya di bagi menjadi tiga golongan yaitu pengeringan dengan udara, suhu panas dan beku. Pengeringan dengan menggunakan oven adalah salah satu teknik yang disebut dengan pengeringan adiabatik, dimana suhu yang digunakan dapat diatur sedemikian rupa sehingga proses pemindahan panas atau penguapan air lebih efektif. Pengeringan dengan oven mempunyai keuntungan karena suhu dan aliran udara dapat di atur sehingga waktur pengeringan dapat ditentukan tepat dan kebersihan dapat diawasi sebaikbaiknya.Pengemasan vakum merupakan sistem utama yang digunakan untruk mengemas dan mempertahankan kualitas alami dari produk-produk daging. Menurut Putu (2001), pengemasan daging sapi dalam kantong plastik hampa udara memberikan beberapa keuntungan yaitu dapat disimpan lebih lama, kebersihan terjamin, terjadi proses aeging sehingga menghasilkan daging yang empuk, penampilan lebih sempurna dan penanganan yang lebih sederhana. Desrosier (2008) mengatakan bahwa seleksi dan pengembangan kemasan yang cocok adalah sama pentingnya dengan formulasi khusus bahan pangan untuk penyimpnanan jangka panjang. Cara penyimpanan vakum lebih baik dibanding cara non vakum dilihat dari susut bobot daging (Nurdjannah dan Sunarlim, 2010). 
Masa simpan daging segar pada suhu $23^{0} \mathrm{C}$ ) relatif hanya dapat bertahan selama 1 sampai 2 hari (Muchtadi dan Sugiyono, 2013).

\section{MATERI DAN METODE PENELITIAN}

Penelitian ini menggunakan rancangan acal lengkap (RAL) berpola $\begin{array}{llllll}\text { petak terbagi dalam } & \text { waktu } & 3 & \mathrm{x} & 4\end{array}$ berulangan 3. Sebagai perlakuan adalah lama pengeringan dan lama penyimpanan. Lama pengeringan (jam) pada suhu $60^{\circ} \mathrm{C}$ sebagai faktor $\mathrm{A}$ (petak utama) $\mathrm{A}_{1}=12$; $A_{2}=16$; dan $A_{3}=20$. Faktor $B$ (anak petak) adalah lama penyimpanan (hari) pada suhu kamar $27^{0} \mathrm{C}$ yaitu $\mathrm{B}_{0}=0 ; \mathrm{B}_{1}=$ $12 ; \mathrm{B}_{2}=24 ;$ dan $\mathrm{B}_{3}=36$. Variabel yang diukur adalah DMA dan SM. Data yang terkumpul dianalisis manggunakan ANOVA dan perlakuan yang berbeda nyata diuji dengan uji beda nyata jujur (BNJ).

Prosedur penelitian dilakukan melalui tahapan berikut: daging sapi segar bagaian paha belakang dibersihkan kemudian dipotong/diiris melintang searah serat dengan ketebalan $1 \mathrm{~cm}$ dengan berat masing-masing 200 gram. Kemudian diblansir pada suhu $80^{\circ} \mathrm{C}$ selama 3 menit.Daging kemudian ditiriskan lalu digantung memakai kawat kecil dan dimasukkan ke dalam oven pada temperature $60^{\circ} \mathrm{C}$ selama 12,16 , dan 20 jam. Selanjutnya didinginkan dan dikemas vakum dengan plastik low density polypropylene $0,3 \mathrm{~mm}$, dan disimpan pada suhu kamar $\left(27^{0} \mathrm{C}\right)$ selama $0,12,24$, dan 36 hari. Selanjutnya dilakukan analisa terhadap DMA dan SM sesuai dengan perlakuan.

\section{HASIL DAN PEMBAHASAN}

Data rataan pengaruh lama pengeringan dan penyimpanan pada suhu kamar terhadap DMA dan SM daging spai blansir yang dikemas vakum dapat dilihat pada Tabel 1 dan Tabel 2.

Pengaruh lama pengeringan dan penyimpanan pada suhu kamar terhadap DMA daging sapi blansir yang dikemas vakum berkisar antara 17,61 sampai 23,11\% (Tabel 1). Analisis sidik ragam menunjukkan bahwa terdapat perbedaan yang sangat nyata $(\mathrm{P}<0,01)$ pengaruh perlakuan terhadap DMA, namun untuk interkasi antar perlakuan berbeda tidak nyata $(\mathrm{P}>0,05)$. Uji BNJ menunjukkan bahwa untuk perlakuan lama pengeringan 12 jam dan 16 jam sama pengaruhnya terhadap DMA namun lebih tinggi dibanding pengeringan 20 jam. 
Tabel 1. Rataan Pengaruh Lama Pengeringan dan Penyimpanan pada Suhu Kamar $\left(27^{0} \mathrm{C}\right)$ terhadap DMA (\%) Daging Sapi Blansir yang Dikemas Vakum.

\begin{tabular}{cccccc}
\hline \multirow{2}{*}{$\begin{array}{c}\text { Lama Pengeringan } \\
60^{\circ} \mathrm{C}(\text { jam })(\mathrm{A})\end{array}$} & 0 & 12 & 24 & 36 & \multirow{2}{*}{ Rataan } \\
\cline { 2 - 5 } & $\left(\mathrm{B}_{0}\right)$ & $\left(\mathrm{B}_{1}\right)$ & $\left(\mathrm{B}_{2}\right)$ & $\left(\mathrm{B}_{3}\right)$ & \\
\hline $12\left(\mathrm{~A}_{1}\right)$ & 26,75 & 24,04 & 23,06 & 21,02 & 23,72 \\
\hline $16\left(\mathrm{~A}_{2}\right)$ & 23,27 & 21,52 & 20,41 & 17,29 & 20,62 \\
\hline $20\left(\mathrm{~A}_{3}\right)$ & 19,31 & 17,26 & 16,76 & 14,52 & 16,96 \\
\hline Rataan & 23,11 & 20,94 & 20,08 & 17,61 & \\
\hline
\end{tabular}

Perlakuan penyimpanan ternyata bahwa penyimpanan 0 hari berbeda sangat nyata $(\mathrm{P}<0,01)$ lebih tinggi dibanding 12, 24 dan 36 hari. Untuk lama penyimpanan 12 hari berbeda tidak nyata DMAnya dengan 24 hari tetapi berbeda sangat nyata lebih tinggi dibanding 36 hari. Demikian halnya dengan penyimpanan 24 hari nyata lebih tinggi DMAnya dibanding 36 hari.

Lama pengeringan 20 jam mempunyai DMA lebih kecil dibanding 12 jam. Hal ini disebabkan karena konveksi panas yang lama dari media oven menyebabkan meningkatnya denaturasi protein sehingga DMA daging sapi blansir menurun. Pada perlakuan lama penyimpanan, nilai DMA semakin menurun dengan semakin lamanya waktu penyimpanan. Hal ini karena gugus reaktif protein semakin berkurang dengan semakin lamanya penyimpanan yang menyebabkan banyaknya air daging terlepas (Aberleet al., 2012). Hal ini sejalan dengan Soeparno (2005) yang mengatakan bahwa penyimpanan dapat menurunkan DMA daging dan mengakibatkan banyaknya air yang berasosiasi dengan protein otot akan meninggalkan serabut otot.

Tabel 2. Rataan Pengaruh Lama Pengeringan dan Penyimpanan pada Suhu Kamar $\left(27^{0} \mathrm{C}\right)$ terhadap SM (\%) Daging Sapi Blansir yang Dikemas Vakum.

\begin{tabular}{cccccc}
\hline \multirow{2}{*}{$\begin{array}{c}\text { Lama Pengeringan } \\
60^{\circ} \mathrm{C}(\text { jam })(\mathrm{A})\end{array}$} & 0 & 12 & 24 & 36 & \multirow{2}{*}{ Rataan } \\
\cline { 2 - 5 } & $\left(\mathrm{B}_{0}\right)$ & $\left(\mathrm{B}_{1}\right)$ & $\left(\mathrm{B}_{2}\right)$ & $\left(\mathrm{B}_{3}\right)$ & \\
\hline $12\left(\mathrm{~A}_{1}\right)$ & 47,90 & 48,68 & 50,98 & 52,20 & 49,94 \\
\hline $16\left(\mathrm{~A}_{2}\right)$ & 48,97 & 50,90 & 52,04 & 53,48 & 51,35 \\
\hline $20\left(\mathrm{~A}_{3}\right)$ & 51,59 & 53,06 & 54,42 & 56,07 & 53,79 \\
\hline Rataan & 49,49 & 50,88 & 52,48 & 53,92 & \\
\hline
\end{tabular}


Pengaruh lama pengeringan dan penyimpanan pada suhu kamar terhadap nilai SM daging sapi blansir yang dikemas vakum berkisar anatara 47,90 sampai $56,07 \%$ (Tabel 2). Analisis sidik ragam menunjukkan bahwa perlakuan lama pengeringan dan penyimpanan memberikan pengaruh yang berbeda sangat nyata $(\mathrm{P}<0,01)$ terhadap nilai $\mathrm{SM}$ daging sapi blansir yang dikemas vakum, sedangkan interaksi keduanya berbeda tidak nyata $(\mathrm{P}>0,05)$. Uji lanjut menunjukkan bahwa lama pengeringan 12 jam memberikan nilai SM lebih rendah dibanding 16 dan 20 jam. Untuk perlakuan lama penyimpanan 0 hari berbeda nyata $(\mathrm{P}<0,05)$ lebih rendah dari 12 hari dan berbeda sangat nyata $(\mathrm{P}<0,01)$ lebih rendah dari 24 dan 36 hari.

Perlakuan lama pengeringan 20 jam mempunyai nilai SM yang lebih besar dibanding 16 dan 20 jam. Hal ini karena pengeringan 20 jam telah mengakibatkan banyaknya cairan daging yang hilang. Terjadinya pelepasan uap air akibat kondisi vakum menyebabkan banyaknya cairan daging yang keluar, namun hal ini masih dalam kisaran normal sebab menurut Soeparno (2005)SM umumnya bervariasi antara 1,5 sampai $54,5 \%$.

\section{KESIMPULAN}

Hasil penelitian menunjukkan bahwa daging sapi blansir yang dikeringkan selama 16 jam pada suhu $60^{\circ} \mathrm{C}$ dan dikemas vakum serta disimpan pada suhu kamar $27^{\circ} \mathrm{C}$ selama 36 hari menghasilkan DMA dan SM dalam standar normal.

\section{DAFTAR PUSTAKA}

Aberle E.D., J.C. Forrest, D.E. Gerrard, and E.W. Mills. 2012. Principles of Meat Science. $14^{\text {th }}$ edition. Kendall Hunt Publ. Co. Iowa, USA.

Desrosier.N.W. 2008. Teknologi Pengawetan Pangan. Penerjemah M. Miljohardjo. UI-Press. Jakarta.

Huff-Lonergen, E., and S.M. Lonergan. 2005. Mechanisms of water-holding capacity of meat: The role of postmoterm biochemical and structural changes. Meat Science 71:194-204

Karel, M. and D.B. Lund. 2003. Physical Principles of Food Preservation. $2^{\text {nd }}$ edition. Marcel Dekker, Inc. New York, USA.

Muchtadi, T.R., dan Sugiyono. 2013. Prinsip, Proses dan Teknologi Pangan. Penerbit Alfabeta. Bandung.

Nurdjannah, R. dan R. Sumarlin. 2010. Pengaruh pengemasan vakum dan suhu penyimpanan terhadap sifat mutu daging domba lockl. Prosiding Seminar Nasional Teknologi Peternakan dan Veteriner:645-653. 
Putu, I.G. 2001.Karakteristik daging dikemas dalam kantong plastik hampa udara (vaccum pack). Wartazoa 11 (2):15-19.

Shanks, B.C., D.M. Wolf, R.J. Maddock. 2002. Tecknocal note: The effect of frezzing on Warner-Bratzler shear force value of beef longissimuss steak across several postmortem aging periods. J. Anim. Sci. 80:2122-2125.

Soeparno. 2005. Ilmu dan Teknologi Daging. Gadjah Mada University Press.Yogyakarta.

Wismer-Pedersen, J. 1987. Chemistry of Animal Tissues. In.The Science of Meat and Meat Product. $3^{\text {rd }}$ edition.Edited by J. F. Price and B.S. Echweigert. Food \& Nutrition Press, Inc. Westport Connecticut, USA. 